\title{
THE EFFECT OF MUDHARABAH, MUSYARAKAH AND MURABAHAH FINANCING ON NET PROFIT IN PT. BANK MUAMALAT INDONESIA, Tbk
}

\author{
Ayu Rumi ${ }^{1}$, Arbanur Rasyid ${ }^{2}$, Ali Hardana ${ }^{3}$, Sulaiman Efendi ${ }^{4}$ \\ ${ }^{1}$ IAIN Padangsidimpuan (Perbankan Syariah, FEBI, IAIN Padangsidimpuan) \\ ${ }^{2}$ IAIN Padangsidimpuan (Hukum Syariah, FEBI, IAIN Padangsidimpuan) \\ ${ }^{3}$ IAIN Padangsidimpuan (Ekonomi Syariah, FEBI, IAIN Padangsidimpuan) \\ ${ }^{4}$ IAIN Padangsidimpuan (Perbankan Syariah, FEBI, IAIN Padangsidimpuan) \\ ayurumi@gmail.com ${ }^{1}$, arbanurrasyid@iain-padangsidimpuan.ac.id ${ }^{2}$, alihardana@iain- \\ padangsidimpuan.ac.id $^{4}$ sulaimanefendi@iain-padangsidimpuan.ac.id $^{5}$
}

\begin{abstract}
ABSTRAK
Penelitian ini merupakan penelitian kuantitatif menggunakan analisis data regresi linier berganda dengan teknik pengumpulan data yang digunakan adalah dokumentasi dan studi kepustakaan. Data diolah menggunakan perhitungan statistik dengan program komputer SPSS 23.0, dengan jumlah sampel sebanyak 53 sampel yang datanya diperoleh melalui situs www.ojk.go.id. Hasil penelitian menunjukkan bahwa secara parsial pembiayaan mudharabah berpengaruh terhadap laba bersih karena nilai $t_{\text {hitung }}>t_{\text {tabel }}(2,011>2,009)$, pembiayaan musyarakah berpengaruh terhadap laba bersih karena nilai $-t_{\text {hitung }}>-t_{\text {tabel }}(-1,925$ $>-2,009)$, dan pembiayaan murabahah berpengaruh terhadap laba bersih karena nilai $t_{\text {hitung }}>$ $t_{\text {tabel }}(2,366>2,009)$. Secara simultan pembiayaan mudharabah, musyarakah dan murabahah berpengaruh terhadap laba bersih karena nilai $F_{\text {hitung }}>F_{\text {tabel }}(5,689>2,79)$. Pengaruh pembiayaan mudharabah, musyarakah dan murabahah terhadap laba bersih sebesar $25,8 \%$, sedangkan sisanya sebesar $74,2 \%$ dipengaruhi oleh faktor lain yang tidak dimasukkan dalam penelitian ini.
\end{abstract}

Kata Kunci: Pembiayaan Muḍhārabah, Musyārakah, Murābahah, Laba Bersih

\section{ABSTRACT}

This research is a quantitative research using multiple linear regression data analysis with data collection techniques used are documentation and literature study. The data was processed using statistical calculations with the SPSS 23.0 computer program, with a total sample of 53 samples whose data was obtained through the website www.ojk.go.id. The results showed that partially mudharabah financing had an effect on net income because the value of $t_{\text {count }}>t_{\text {table }}(2,011>2,009)$, musyarakah financing had an effect on net income because the value of $-t_{\text {count }}>-t_{\text {table }}(-1,925>-2,009)$, and murabahah financing had an effect on profit. net because the value of $t_{\text {count }}>t_{\text {table }}(2,366>2,009)$. Simultaneously, mudharabah, musyarakah and murabahah financing affect net income because the value of $F_{\text {count }}>F_{\text {table }}$ (5.689 > 2.79). The effect of mudharabah, musyarakah and murabahah financing on net income is $25.8 \%$, while the remaining $74.2 \%$ is influenced by other factors not included in this study.

Keywords: Muḍhārabah, Musyārakah, Murābahah Financing, Net Profit 


\section{POINT}

\section{Journal Of Sharia Banking}

\section{A. PENDAHULUAN}

Bank syariah sebagai lembaga intermediasi masyarakat memiliki peranan yang sangat penting. Tugas dari bank syariah sebagai lembaga intermediasi adalah menghimpun dana dari masyarakat dan menyalurkannya kepada masyarakat yang memerlukannya. Salah satu kegiatan bank syariah adalah melakukan kegiatan pembiayaan, yaitu menyalurkan dana kepada orang-orang yang membutuhkan dana. Bank syariah sebagai lembaga pembiayaan dalam melakukan kegiatannya harus sesuai dengan syariat Islam, dan tidak boleh bertentangan dengan syariat. Karena konsep dasar bank syariah didasarkan pada al-Quran dan hadis Rasulullah SAW. Kegiatan bank syariah dalam hal pembiayaan yang sesuai dengan syariat Islam telah diatur oleh UU RI tentang Perbankan Syariah pasal 19 No.21 Tahun 2008.

Pada hakikatnya baik bank konvensional maupun bank syariah berorientasi pada laba (profit oriented). Namun yang membedakannya adalah bank syariah tidak mengenal istilah bunga dalam memberikan jasa kepada nasabah penyimpan maupun nasabah pembiayaan. Di bank syariah keuntungan yang diberikan disesuaikan dengan prinsip syariah sesuai dengan hukum islam.

Pembiayaan adalah aktivitas bank syariah dalam menyalurkan dana kepada pihak lain selain bank berdasarkan prinsip syariah. Pembiayaan yang diberikan oleh bank syariah kepada nasabah akan berpengaruh pada peningkatan profitabilitas bank, hal ini dapat tercermin pada perolehan laba. Dengan adanya peningkatan laba usaha bank akan menyebabkan kenaikan tingkat laba bersih yang diterima oleh bank.

Adapun beberapa pembiayaan yang diberikan oleh PT. Bank Muamalat Indonesia Tbk yaitu Mudharabah, Musyarakah dan Murabahah. Berikut dapat dilihat perkembangan pembiayaan tersebut dan laba bersih pada PT. Bank Muamalat Indonesia, Tbk dari tahun 2010 hingga tahun 2018.

Tabel 1

Pembiayaan Muḍhārabah, Musyārakah, Murābahah dan Laba Bersih pada PT. Bank Muamalat Indonesia Tbk Periode 2010-2018

\begin{tabular}{|c|c|c|c|c|}
\hline Tahun & Mựhārabah & Musyārakah & Muräbahah & Laba Bersih \\
\hline 2010 & 1.410 & 6.100 & 6.596 & 170 \\
\hline 2011 & 1.564 & 8.350 & 10.273 & 273 \\
\hline 2012 & 2.039 & 13.005 & 16.345 & 46 \\
\hline 2013 & 2.230 & 18.670 & 19.570 & 165 \\
\hline 2014 & 1.720 & 19.550 & 20.170 & 59 \\
\hline 2015 & 1.050 & 20.190 & 17.310 & 74 \\
\hline 2016 & 828,8 & 20.900 & 17.500 & 81 \\
\hline 2017 & 737,2 & 19.900 & 19.700 & 26 \\
\hline 2018 & 438 & 16.544 & 15.632 & 46 \\
\hline
\end{tabular}

Sumber: Laporan PT. Bank Muamalat Indonesia, Tbk

Portofolio pembiayaan PT. Bank Muamalat Indonesia, Tbk dari tahun 2010 sampai dengan 2018 masih mengalami naik turun. Pembiayaan mudharabah tahun 2011 sebesar Rp1.564 miliar meningkat 10,92 persen dibandingkan pada akhir tahun 2010 sebesar Rp 1.410 miliar. Pada tahun 2012 pembiayaan 


\section{Journal Of Sharia Banking}

mudharabahPT. Bank Muamalat Indonesia, Tbk sebesar Rp 2.039 miliar mengalami peningkatan sebesar 30,37 persen dari tahun 2011 sebesar Rp 1.564 miliar. Pada tahun 2013 pembiayaan mudharabah sebesar Rp 2.230 miliar mengalami penurunan sebesar 9,36 persen dari tahun 2012 sebesar Rp 2.039 miliar. Pada tahun 2014 pembiayaan mudharabah menurun sebesar 22,86 persenyang pada akhir tahun 2013 sebesar Rp 2.230 miliar. Pada tahun 2015 pembiayaan mudharabah sebesar $\mathrm{Rp} 1.050$ miliar mengalami penurunan sebesar 38,95 persen yang pada tahun 2014 sebesar Rp 1.720 miliar. Pada tahun 2017 pembiayaan mudharabah mengalami penurunan sebesar 11.05 persen menjadi $\mathrm{Rp} 737,2$ miliar yang pada tahun 2016 hanya sebesar Rp 828,8 miliar. Dan pada tahun 2018 pembiayaan mudharabah mengalami penurunan sebesar 40,58 persen menjadi Rp.438 miliar.

Dilihat dari perkembangan pembiayaan mudharabah pada tahun 2012 yang mengalami peningkatan dari tahun 2011 justru tidak mendukung pertumbuhan laba bersih yang ada pada tahun 2012. Pertumbuhan laba bersih pada tahun 2012 mengalami penurunan dari tahun 2011. Pada tahun 2015 dan 2016 hal demikian juga terjadi. Fenomena ini berbanding terbalik dengan teori yang menyatakan bahwa pertumbuhan laba akan meningkat apabila perkembangan pembiayaan meningkat.

Pembiayaan musyarakah tahun 2010 sebesar Rp 6.100 miliar meningkat menjadi Rp 8.350 miliar pada akhir tahun 2011. Pada tahun
2013 pembiayaan musyarakah sebesar Rp 18.670 miliar mengalami penurunan sebesar 43,56 persen yang pada akhir tahun 2012 hanya sebesar Rp 13.005 miliar. Pada tahun 2014 pembiayaan musyarakah sebesar Rp 19.550 miliar mengalami peningkatan sebesar 3,27 persenyang pada akhir tahun 2015 menjadi sebesar Rp 20.190 miliar. Pada tahun 2016 pembiayaan musyarakahsebesar Rp 20.900 miliar mengalami peningkatan sebesar 4,78 persen yang pada tahun 2017 menjadi Rp 19.900 miliar. Dan pada tahun 2018 pembiayaan musyarakah mengalami penurunan sebesar 16,86 persen menjadi 16.544 miliar.

\section{Perkembangan pembiayaan} musyarakah juga mengalami naik turun setiap tahunnya, hal yang sama juga terjadi pada pembiayaan musyarakah yaitu pada tahun 2012 perkembangan pembiayaan musyarakah meningkat tetapi pertumbuhan laba bersih menurun, begitu juga yang terjadi pada tahun 2014. Fenomena ini juga tidak sesuai dengan teori yang ada bahwa pertumbuhan laba bersih akan meningkat apabila perekembangan pembiayaan meningkat.

Pembiayaan murabahah tahun 2011 sebesar Rp 10.275 miliar meningkat sebesar 55,74 persen yang pada tahun 2010 hanya sebesar Rp 6.596 miliar. Pada tahun 2013 pembiayaan murabahah sebesar Rp 19.570 miliar mengalami peningkatan sebesar 3,06 persenyang pada akhir tahun 2014 menjadi sebesar Rp 20.170 miliar. Pada tahun 2015 


\section{Journal Of Sharia Banking}

pembiayaan murabahah sebesar $\mathrm{Rp} 17.310$ miliar mengalami penurunan sebesar 14,17 persen yang pada akhir tahun 2014 sebesar Rp 20.170 miliar. Pada tahun 2017 pembiayaan murabahah sebesar Rp 19.700 miliar mengalami peningkatan dari tahun 2016 yang hanya sebesar Rp 17.500 miliar. Dan pada tahun 2018 pembiayaan murabahah mengalami penurunan sebesar 120,64 persen menjadi Rp.15.632 miliar.

Berdasarkan penjelasan diatas, maka peneliti tertarik untuk melakukan penelitian ini karena dalam penelitian terdahulu masih banyak perbedaan dalam hasil yang diteliti dalam setiap periodenya. Hal ini berdasarkan permasalahan diatas maka peneliti melakukan penelitian lebih lanjut dengan judul "Pengaruh Pembiayaan Mudharabah, Musyarakah Dan Murabahah Terhadap Laba Bersih Pada PT. Bank Muamalat Indonesia Tbk".

\section{B. METODE}

Jenis penelitian ini adalah kuantitatif untuk menjelaskan kedudukan variabel-variabel yang diteliti serta hubungan antara satu variabel dengan variabel lainnya. Data kuantitatif adalah data yang diukur dalam skala numerik (angka). Data yang dipakai dalam penelitian ini berupa data sekunder. Data sekunder adalah data yang diperoleh secara tidak langsung oleh peneliti, akan tetapi melalui orang lain atau dokumen. Dalam pengumpulan data peneliti menggunakan metode dokumentasi, yang diperoleh dari PT. Bank
Muamalat Indonesia Tbk buku-buku terkait judul penelitian, jurnal yang memuat artikelartikel terkait penelitian, internet, dan sumber lainnya yang terkait.

Sampel dari penelitian ini adalah data pembiayaan mudharabah, musyarakah dan murabahah yang diambil dari tahun 2015-2019 melalui situs www.bankmuamalat.co.id. Penelitian ini dalam kurun waktu 2015-2019 berarti selama 5 tahun dengan laporan keuangan pembiayaan mudharabah, musyarakah dan murabahah dan laba bersih sebanyak 1 tahun yaitu 12 bulan $\times 5$ sehingga jumlahnya ada 60 sampel. Metode analisis data yang digunakan dalam penelitian ini adalah metode analisis data dengan bantuan SPPS Versi 23.

\section{HASIL DAN PEMBAHASAN}

Hasil Uji Persial (Uji t)

Coefficientsa

\begin{tabular}{|c|c|c|}
\hline & & \\
Model & $\mathrm{T}$ & Sig. \\
\hline (Constant) & 4.502 & .000 \\
PMd & 2.011 & .015 \\
PMs & -1.925 & .000 \\
PMr & 2.366 & .002 \\
\hline
\end{tabular}

Sumber: Hasil Output SPSS Versi 23.00, data diolah

Uji parsial dengan t-test digunakan untuk mengetahui apakah secara parsial pembiayaan mudharabah, musyarakah dan murabahah memiliki pengaruh atau tidak terhadap laba bersih. Pengujian yang dilakukan peneliti berdasarkan t-hitung. 


\section{POINT}

\section{Journal Of Sharia Banking}

Nilai $t_{\text {hitung }}>t_{\text {tabel }}(2,011>2,009)$, maka HO ditolak, jadi dapat disimpulkan bahwa secara parsial pembiayaan mudharabah memiliki pengaruh yang signifikan terhadap laba bersih.

Nilai $-t_{\text {hitung }}>-t_{\text {tabel }}(-1,925>-2,009)$, maka HO ditolak, jadi dapat disimpulkan bahwa secara parsial pembiayaan musyarakah memiliki pengaruh terhadap laba bersih.

Nilai $t_{\text {hitung }}>t_{\text {tabel }}(2,366>2,009)$, maka HO ditolak, jadi dapat disimpulkan bahwa secara parsial pembiayaan murabahah memiliki pengaruh yang signifikan terhadap laba bersih.

Hasil Uji Simultan (Uji F)

ANOVAa

\begin{tabular}{|l|l|l|}
\hline Model & F & Sig. \\
\hline $\begin{array}{l}\text { Regression } \\
\text { Residual }\end{array}$ & 5.689 & $.002 \mathrm{~b}$ \\
Total & & \\
\hline
\end{tabular}

a. Dependent Variable: Ib

b. Predictors: (Constant), pmr, pmd, pms

Sumber: Hasil Output SPSS Versi 23.00, data diolah

Berdasarkan pengujian di atas dapat diketahui bahwa $F_{\text {hitung }}>F_{\text {tabel }}(5,689>2,79)$ maka HO ditolak, artinya pembiayaan mudharabah, musyarakah dan murabahah memiliki pengaruh secara simultan terhadap laba bersih.

Hasil Uji Determinasi (R2)

\begin{tabular}{|l|l|l|l|l|}
\hline \multicolumn{5}{|c|}{ Model Summaryb } \\
Model & $\mathrm{R}$ & $\begin{array}{l}\mathrm{R} \\
\text { Square }\end{array}$ & $\begin{array}{l}\text { Adjusted R } \\
\text { Square }\end{array}$ & $\begin{array}{l}\text { Std. Error of the } \\
\text { Estimate }\end{array}$ \\
\hline 1 & $.508 \mathrm{a}$ & .258 & .213 & 45368.46545 \\
\hline
\end{tabular}

a. Predictors: (Constant), pmr, pmd, pms

b. Dependent Variable: Ib

Sumber: Hasil Output SPSS Versi 23.00, data diolah

Keterangan Hasil Uji Normalitas

\begin{tabular}{|l|l|l|l|l} 
No & Variabel & Asymp.Sig (2- & Hasil & Keterangan
\end{tabular}




\section{POINT}

\begin{tabular}{|c|c|c|c|c|}
\multicolumn{4}{|c}{ Journal Of Sharia Banking } \\
\hline 1 & & tailed) & & \\
\hline 2 & LB & 0,200 & $0,200>0,05$ & Terdistribusi normal \\
\hline 3 & PMs & 0,060 & $0,060>0,05$ & Terdistribusi normat Hasil Uji Linearitas Laba Bersih dan Pembiayaan \\
\hline 4 & PMr & 0,150 & $0,150>0,05$ & Terdistribusi normal \\
Munābahah \\
ANOVA Table
\end{tabular}

Hasil Uji Linearitas Laba Bersih dan Pembiayaan Muḍhārabah ANOVA Table

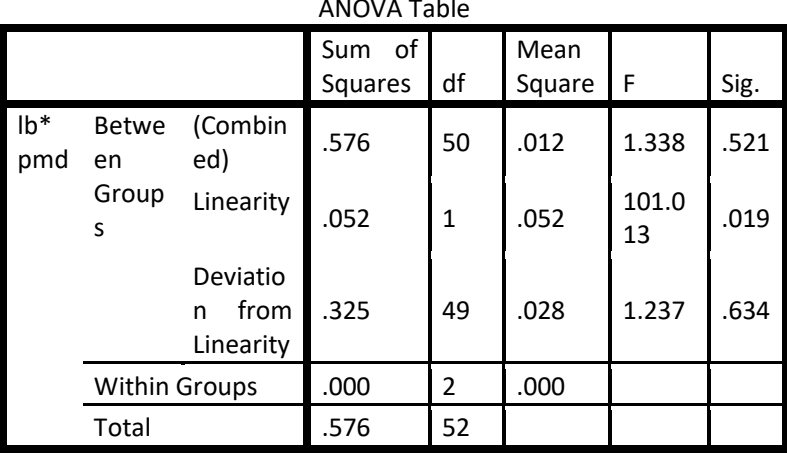

Sumber: Hasil Output SPSS Versi 23.00, data diolah

Dari output di atas dapat diketahui bahwa nilai signifikansi pada linearity sebesar 0,019. Berarti nilai signifikansi linearity 0,019< 0,05, jadi dapat disimpulkan model dalam regresi ini memiliki hubungan yang linier.

Hasil Uji Linearitas Laba Bersih dan Pembiayaan Musyārakah

\begin{tabular}{|c|c|c|c|c|c|c|c|}
\hline \multicolumn{8}{|c|}{ ANOVA Table } \\
\hline & & & $\begin{array}{l}\text { Sum of } \\
\text { Squares }\end{array}$ & Df & $\begin{array}{l}\text { Mean } \\
\text { Square }\end{array}$ & $F$ & Sig. \\
\hline & & $\begin{array}{l}\text { (Combin } \\
\text { ed) }\end{array}$ & .576 & 50 & .012 & & .521 \\
\hline & & Linearity & .040 & 1 & .040 & 103.132 & .036 \\
\hline & $\begin{array}{l}\text { Gro } \\
\text { ups }\end{array}$ & $\begin{array}{l}\text { Deviatio } \\
n \text { from } \\
\text { Linearity }\end{array}$ & .276 & 49 & .030 & & .514 \\
\hline & \multicolumn{2}{|c|}{ Within Groups } & .000 & 2 & .000 & & \\
\hline & \multicolumn{2}{|c|}{ Total } & .576 & 52 & & & \\
\hline
\end{tabular}

Sumber: Hasil Output SPSS Versi 23.00, data diolah

Dari output di atas dapat diketahui bahwa nilai signifikansi pada linearity sebesar 0,036 . Berarti nilai signifikansi linearity $0,036<$ 0,05, jadi dapat disimpulkan model dalam regresi ini memiliki hubungan yang linier.

\begin{tabular}{|c|c|c|c|c|c|c|c|}
\hline & & & $\begin{array}{l}\text { Sum of } \\
\text { Squares }\end{array}$ & Df & $\begin{array}{l}\text { Mean } \\
\text { Square }\end{array}$ & $\mathrm{F}$ & Sig. \\
\hline \multirow[t]{3}{*}{ lb* pmr } & $\begin{array}{l}\text { Between } \\
\text { Groups }\end{array}$ & $\begin{array}{l}\text { (Combined) } \\
\text { Linearity } \\
\text { Deviation } \\
\text { from } \\
\text { Linearity }\end{array}$ & $\begin{array}{l}.576 \\
.035 \\
.469\end{array}$ & $\begin{array}{l}50 \\
1 \\
49\end{array}$ & $\begin{array}{l}.012 \\
.035 \\
.010\end{array}$ & $\begin{array}{l}1.338 \\
124.102 \\
\\
2.015\end{array}$ & $\begin{array}{l}.521 \\
.042 \\
.709\end{array}$ \\
\hline & \multicolumn{2}{|c|}{ Within Groups } & .000 & 2 & .000 & & \\
\hline & \multicolumn{2}{|l|}{ Total } & .576 & 52 & & & \\
\hline
\end{tabular}

Sumber: Hasil Output SPSS Versi 23.00, data diolah

Dari hasil output di atas dapat diketahui bahwa nilai signifikansi pada linearity sebesar 0,042 . Berarti nilai signifikansi $0,042<0,05$, jadi dapat disimpulkan model regresi ini memiliki hubungan yang linier.

Hasil Uji Multikolinearitas Coefficientsa

\begin{tabular}{|l|l|l|}
\hline \multirow{2}{*}{ Model } & \multicolumn{2}{|l|}{ Collinearity Statistics } \\
\cline { 2 - 3 } (Constant) & Tolerance & VIF \\
PMd & .565 & \\
PMs & .557 & 1.770 \\
PMr & .743 & 1.794 \\
\hline
\end{tabular}

Sumber: Hasil Output SPSS Versi 23.00, data diolah

Keterangan Hasil Uji Multikolinearitas

\begin{tabular}{|c|c|c|c|c|}
\hline No & Variabel & $\begin{array}{c}\text { Nilai } \\
\text { VIF }\end{array}$ & $\begin{array}{c}\text { Syarat Uji } \\
\text { Multikolinearitas }\end{array}$ & Keterangan \\
\hline 1 & PMd & 1,770 & $<10$ & $\begin{array}{c}\text { Tidak terjadi } \\
\text { multikolinearitas }\end{array}$ \\
\hline 2 & PMs & 1,794 & $<10$ & $\begin{array}{c}\text { Tidak terjadi } \\
\text { multikolinearitas }\end{array}$ \\
\hline 3 & PMr & 1,346 & $<10$ & $\begin{array}{c}\text { Tidak terjadi } \\
\text { multikolinearitas }\end{array}$ \\
\hline
\end{tabular}

Berdasarkan tabel di atas nilai dari Variance Inflation Factor (VIF) dari ketiga variabel kurang dari 10, sehingga dapat disimpulkan bahwa tidak terjadi multikolinearitas antar variabel bebasnya. 


\section{Journal Of Sharia Banking}

Hasil Uji Heteroskedastisitas

Scatterplot

Dependent Variable: LB

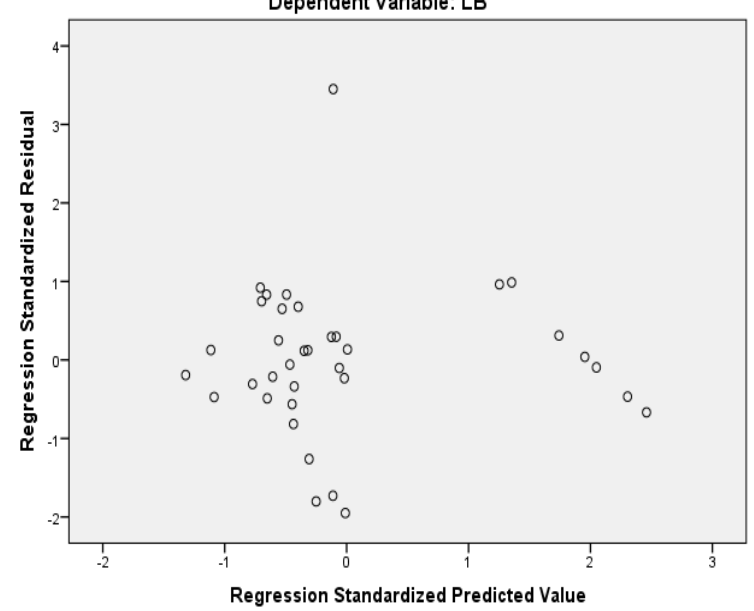

Sumber: Hasil Output SPSS Versi 23.00, data diolah

Berdasarkan gambar IV.1 di atas dapat diketahui bahwa titik-titik membentuk pola yang tidak jelas dan titik-titik menyebar diatas dan dibawah angka 0 pada sumbu $Y$. Oleh karenanya dapat disimpulkan bahwa tidak terjadi masalah heteroskedastisitas pada model regresi.

\section{Hasil Uji Autokorelasi}

\begin{tabular}{|l|l|l|l|l|l|}
\hline $\begin{array}{l}\text { Mo } \\
\text { del }\end{array}$ & $R$ & $\begin{array}{l}\text { R } \\
\text { Square }\end{array}$ & $\begin{array}{l}\text { Adjusted } \\
\text { R Square }\end{array}$ & $\begin{array}{l}\text { Std. Error of } \\
\text { the Estimate }\end{array}$ & $\begin{array}{l}\text { Durbin- } \\
\text { Watson }\end{array}$ \\
\hline 1 & $.508 a$ & .258 & .213 & 45368.46545 & 1.795 \\
\hline
\end{tabular}

a. Predictors: (Constant), pmr, pmd, pms

b. Dependent Variable: Ib

Sumber: Hasil Output SPSS Versi 23.00, data diolah

Berdasarkan output diatas, maka dapat dijelaskan nilai DW sebesar 1,795 dan nilai du sebesar 1,6785, sehingga $d u<d w<4-d u$ $(1,6785<1,795<2,3215)$ dengan demikian dapat disimpulkan tidak terjadi masalah autokorelasi.
Hasil Analisis Regresi Linier Berganda

\begin{tabular}{|c|c|c|c|c|c|}
\hline \multirow[b]{3}{*}{ Model } & & & \multicolumn{3}{|c|}{ Coefficientsa } \\
\hline & \multicolumn{2}{|c|}{$\begin{array}{l}\text { Unstandardize } \\
\text { d Coefficients }\end{array}$} & \begin{tabular}{|l} 
Standar \\
dized \\
Coeffici \\
ents \\
\end{tabular} & \multirow[b]{2}{*}{$\mathrm{t}$} & \multirow[b]{2}{*}{ Sig. } \\
\hline & B & $\begin{array}{l}\text { Std. } \\
\text { Error }\end{array}$ & Beta & & \\
\hline 1 (Constant) & $\begin{array}{l}109034 \\
.232\end{array}$ & $\begin{array}{l}99895 \\
.488\end{array}$ & & 4.502 & .000 \\
\hline PMd & .094 & .026 & .638 & 2.011 & .015 \\
\hline PMs & -.011 & .005 & -.261 & -1.925 & .000 \\
\hline $\mathrm{PMr}$ & .003 & .004 & .160 & 2.366 & .002 \\
\hline
\end{tabular}

a. Dependent Variable: Ib

Sumber: Hasil Output SPSS Versi 23.00, data diolah

Berdasarkan tabel IV.17 di atas menggambarkan persamaan regresi untuk mengetahui nilai konstanta. Persamaan dalam penelitian ini adalah:

$$
\begin{gathered}
\mathrm{LB}=109.034,232+0,094 \mathrm{PMd}-0,011 \mathrm{PMs}+ \\
\text { 0,003 PMr }
\end{gathered}
$$

Keterangan:

LB = Variabel dependen (laba bersih)

$\beta 0=$ Konstanta

$\beta 1, \beta 2, \beta 3=$ Koefisien

PMd = Variabel independen (pembiayaan mudharabah)

PMs = Variabel independen (pembiayaan musyarakah)

$\mathrm{PMr}=$ Variabel independen (pembiayaan murabahah)

\section{PENUTUP}

\section{Kesimpulan}

Berdasarkan hasil penelitian, nilai $\mathrm{R}^{2}$ sebesar 0,258 , artinya persentase sumbangan pengaruh pembiayaan mudharabah, 


\section{Journal Of Sharia Banking}

musyarakah dan murabahah terhadap laba bersih sebesar $25,8 \%$. Sedangkan sisanya sebesar $74,2 \%$ dipengaruhi atau dijelaskan oleh variabel lain yang tidak dimasukkan dalam model penelitian ini. Maka peneliti mengambil kesimpulan sebagai berikut:

1. Pembiayaan mudharabah memiliki nilai $t_{\text {hitung }}$ $>t_{\text {tabel }}$ yaitu 2,011 $>2,009$ artinya pembiayaan mudharabah berpengaruh terhadap laba bersih PT. Bank Muamalat Indonesia Tbk.

2. Pembiayaan musyarakah memiliki nilai $-t_{\text {hitung }}$ $>-t_{\text {tabel }}$ yaitu $-1,925>-2,009$ artinya pembiayaan musyarakah berpengaruh terhadap laba bersih PT. Bank Muamalat Indonesia Tbk.

3. Pembiayaan murabahah memiliki nilai $t_{\text {hitung }}$ $>t_{\text {tabel }}$ yaitu $2,366>2,009$ artinya pembiayaan murabahah berpengaruh terhadap laba bersih PT. Bank Muamalat Indonesia Tbk.

4. Pembiayaan mudharabah, musyarakah dan murabahah memiliki nilai $F_{\text {hitung }}>F_{\text {tabel }}$ yaitu 5,689 > 2,79, maka dapat disimpulkan bahwa pembiayaan mudharabah, musyarakah dan murabahah berpengaruh secara simultan terhadap laba bersih PT. Bank Muamalat Indonesia Tbk.

\section{Saran}

Berdasarkan kesimpulan diatas maka saran-saran yang dapat diberikan peneliti adalah sebagai berikut:
1. Bagi PT. Bank Muamalat Indonesia Tbk diharapkan mampu memperbaiki tingkat pembiayaan yang sangat berpengaruh terhadap laba bersih.

2. Bagi peneliti yang akan meneliti selanjutnya diharapkan untuk memperluas variabel dalam penelitian kedepannya agar tidak hanya focus pada variabel pembiayaan saja karena masih banyak variabel lain yang mempengaruhi laba bersih.

\section{DAFTAR PUSTAKA}

Adiwarman A. Karim, Bank Islam (Analisis Fiqh dan Keuangan), Jakarta: PT. GrafindoPersada, 2013.

Ascarya, Akad dan Produk Bank Syariah, Jakarta: Rajawali Pers, 2013.

Asep Hermawan, Penelitian Bisnis Paradigma Kuantitatif, Jakarta: PT. Grasindo, 2009.

Bank Muamalat Indonesia, Laporan Publikasi Triwulanan, Jakarta: Bank Muamalat Indonesia,

http://www.bankmuamalat.co.id/hubunga n-investor/laporan-tahunan (diakses 10 Februari 2019).

Bambang Prasetyo dan Lina Miftahul Jannah, Metode Penelitian Kuantitatif: Teori dan Aplikasi, Jakarta: PT. Raja Grafindo Persada, 2010.

Departemen Agama RI, Al-Quran danTerjemahannya.

Duwi Priyatno, SPSS 22 Pengolah Data Terpraktis, Yogyakarta: CV. Andi Offset, 2014.

Dwi Suwikyo, Kamus Lengkap Ekonomi Islam, Jakarta: PT. Grafindo Persada, 2008. 


\section{Journal Of Sharia Banking}

Hasibuan Melayu S.P, Dasar-Dasar Perbankan, Jakarta: Bumi Aksara, 2011.

Hery, Teori Akuntansi, Jakarta: Kencana, 2011.

Ismail, Perbankan Syariah, Jakarta: Kencana Prenada Media Group, 2011.

Kasmir, Bank dan Lembaga Keuangan Lainnya, Jakarta: Rajawali Pers, 2013.

- Manajemen Perbankan, Jakarta: PT. Raja Grafindo Persada, 2004.

Muhammad Firdaus, Ekonometrika: Suatu Pendekatan Aplikatif, Jakarta: Bumi Aksara, 2011.

Muhammad, Manajemen Pembiayaan Mudharabah Di Bank Syariah, Jakarta: Rajawali, 2008.

_ Manajemen Dana Bank Syariah, Jakarta: Rajawali Pers, 2014.

Muhammad Nasib ar'Rifa'l, Taisiru al-Aliyyul Qadir li Ikhtishari Tafsir Ibnu Katsir, Jilid2, Jakarta: GEMA INSANI PRESS, 1999.

Muhammad Teguh, Metodologi Penelitian Ekonomi Teori dan Aplikasi, Jakarta: PT. Raja Grafindo Persada, 2005.

Moh Nazir, Metode Penelitian, Bogor: Ghalia Indonesia, 2011.
Nachrowi Djalal, Ekonometrika Untuk Analisis Ekonomi dan Keuangan, Jakarta: Lembaga Penerbit Fakultas Ekonomi UI, 2006.

Setiawan dan Dwi Endah Kusrini, Ekonometrika, Yogyakarta: CV. Andi, 2010.

Shihab.M Quraish, Tafsir Al-Misbah: Pesan, Kesan Dan Keserasian Al-Quran Volume 3, Jakarta: Lentera Hati, 2002.

Slamet Haryono, Analisis Laporan Keuangan Perbankan Syariah, Yogyakarta: Pustaka Sayid Sabiq, 2009.

Sugiyono, Statistika untuk Penelitian, Bandung: ALFABETA, 2006.

-Metode Penelitian Kuantitatif Kualitatif dan R \& D, Bandung: Alfabeta, 2016.

Toha Anggoro, Metode Penelitian, Jakarta: Universitas Terbuka, 2007.

Undang-Undang Republik Indonesia No. 21 Tahun 2008 tentang Perbankan Syariah.

Veithzal Rivai dan Arviyan Arifin, Islamic Banking: Sebuah Teori, Konsep, dan Aplikasi, Jakarta: Bumi Aksara, 2010.

Warkum Sumitro, Asas-Asas Perbankan Islam dan Lembaga-Lembaga Terkait, Jakarta: PT. Raja Grafindo Persada, 1996.

Zainuddin Ali, Hukum Perbankan Syariah, Jakarta: Sinar Grafika, 2008. 